\title{
Trade-offs in make-buy decisions
}

\author{
Mandar Dabhilkar
}

\section{Linköping University Post Print}

N.B.: When citing this work, cite the original article.

Original Publication:

Mandar Dabhilkar, Trade-offs in make-buy decisions, 2011, Journal of Purchasing and Supply Management, (17), 3, 158-166.

http://dx.doi.org/10.1016/j.pursup.2011.04.002

Copyright: Elsevier http://www.elsevier.com/

Postprint available at: Linköping University Electronic Press

http://urn.kb.se/resolve?urn=urn:nbn:se:liu:diva-71553 


\title{
TRADE-OFFS IN MAKE-BUY DECISIONS
}

\author{
Mandar Dabhilkar a, b \\ ${ }^{a}$ School of Industrial Engineering and Management, Department of Industrial Economics and \\ Management, KTH - Royal Institute of Technology, 10044 Stockholm, Sweden \\ ${ }^{\mathrm{b}}$ KITE Research Group, Linköping University, 58183 Linköping, Sweden \\ E-mail: mandar.dabhilkar@indek.kth.se
}

\begin{abstract}
While the previous literature uses transaction cost economics and the resource-based view to theoretically derive the benefits of outsourcing, it has so far overlooked how these theoretical underpinnings must be used to assess trade-offs involved in make-buy decisions as well. This study investigates trade-offs in make-buy decisions for the buying firm. It takes an operations strategy perspective and links manufacturing firms' competitive priorities to outsourcing motives and resulting capabilities. Survey data from a representative sample of 136 manufacturing plants in Sweden is subjected to regressions analysis. In contrast to earlier empirical research, this study shows that resulting capabilities of strategic outsourcing initiatives are distinct, and furthermore, do not emerge cumulatively. This has important implications for the ongoing debate over tradeoffs in the operations strategy literature. Findings are clearly in support of the trade-off model and extend current research into the theoretical domain of make-buy decisions.
\end{abstract}

Keywords: Operations strategy, make-buy decision, trade-offs 


\section{Introduction}

While current theory is able to explain the underlying rationales behind different motives to outsource manufacturing, it fails to consider that these motives often conflict. As an example, studies single out lower costs and greater flexibility as among the main motives to outsource manufacturing (e.g., Ulrich and Ellison, 2005). Ulrich and Ellison (2005) argue that the rationale behind the lower costs is that suppliers with several customers can achieve greater economies of scale than individual customers could on their own. Furthermore, they propose that the rationale behind suppliers' greater flexibility is their ability to pool demand from several customers, since the variability in demand at the supplier stage will be less than that of their individual customers. Yet although each of these rationales is true, it is wrong to assume that lower costs and greater flexibility are achieved simultaneously when outsourcing manufacturing. Rather, the present study argues that these motives are in conflict, implying that improvements in their corresponding performance indicators have to be traded off when outsourcing manufacturing.

The purpose of this study is to add to the debate over trade-offs in operations strategy by extending the literature into the theoretical domain of make-buy decisions. So far, this debate has focused on whether or not there is a need for trade-offs within the factory walls of the focal firm (Boyer and Lewis, 2002; Rosenzweig and Roth, 2004). However, as firms become less vertically integrated, the scope of analysis must be broadened to a greater share of the supply chain (Gupta, Verma and Victorino, 2006; Hayes, 2002). Therefore, the present study includes make-buy decisions.

\section{Theoretical frame of reference and hypothesis development}

\subsection{Trade-offs in operations strategy}


Wickham Skinner introduced the idea of trade-offs in operations strategy in his seminal Harvard Business Review articles in 1969 and 1974. The US manufacturing sector was in crisis; in order to prevail, he argued, companies had to prioritise among a set of competitive priorities, namely cost, quality, speed and flexibility. Firms neglecting to do so, sacrificing performance in some objectives in order to excel in others, would simply end up second best in all. The underlying logic here is that manufacturing firms are viewed as technologically constrained systems, with inherent limitations in equipment, space, process technology, and other resources such as labor and capital. All of these limitations make trade-offs in the decision-making process inevitable. Therefore, to be competitive, a company has to focus its efforts and resources on one specific mission. This type of manufacturing strategy, well known as the focused factory, advocates ranking strategic objectives and then targeting one objective at a time. The effectiveness of an operations strategy is determined by the degree of consistency among competitive priorities and corresponding decisions regarding operational structure and infrastructure. The make-buy decision is such a decision.

However, Skinner's idea of having to make trade-offs when implementing operations strategy has been challenged since the mid 1980s (e.g., Ferdows and De Meyer, 1990; Nakane, 1986). In sharp contrast to Skinner's trade-off model, these scholars suggest an alternative, namely the sand cone model. They were mainly inspired by the experiences of successful Japanese firms such as Toyota, also known as world-class manufacturing (Schonberger, 1986). Their main reason for proposing the sand cone model was that world-class manufacturers could improve several performance objectives simultaneously without having to make trade-offs such as that between cost and flexibility.

In retrospect, the main merit of advocating the sand cone model is that it has spurred a debate over trade-offs that has sharpened the understanding of fundamentals in operations 
strategy. In particular, a special issue of Production and Operations Management (Benningson, 1996; Clark, 1996; Hayes and Pisano, 1996; Skinner, 1996) and two notes in the Journal of Operations Management (Schmenner and Swink, 1998; Vastag, 2000) have been instrumental in clarifying the issues involved. In summary, the main thrust is that although trade-offs in operations strategy remain on an overall level, certain advanced manufacturing practices can help to resolve often conflicting priorities, such as cost and flexibility, simultaneously. The logic here is that a firm can indeed move from one performance frontier to another, more efficient frontier by world-class manufacturing practices without trade-offs. But in the process the firm has to differentiate its offering to the marketplace by finding a unique position on the new frontier, and any move on the new frontier will create a trade-off. Schmenner and Swink (1998) and Vastag (2000) explain the theoretical underpinnings for this: A firm's proximity to its frontier indicates whether it may acquire cumulative capabilities or if it is subject to trade-offs among capabilities. Factories may achieve multiple capabilities simultaneously when they are operating far away from their performance frontiers. However, as a factory approaches its performance frontier (i.e., becomes fully utilised), building capabilities requires more resources and intensifies the need for focus. Thus, the trade-off model is most applicable to firms operating near their performance frontier.

So why is there a need to further understand trade-offs in operations strategy? The above discussion shows that the cumulative and trade-off models coexist in industrial practice and theory. The cumulative model works for firms far away from their performance frontiers. As firms approach these frontiers, the trade-off model is more applicable, as has been empirically validated by Lapre and Scudder (2004).

Yet there are two motivations for additional trade-off studies. First, despite the deeper understanding of the issues involved, the debate continues. As an example in favor of the sand 
cone model of cumulative capability development, Rosenzweig and Roth (2004, p. 366) maintain that the development of one generic manufacturing capability need not necessarily be at the expense of another.

Secondly and more importantly, the debate over trade-offs has so far only had an internal focus, while simultaneously there has been a tremendous increase in outsourced manufacturing. The trend toward increased outsourcing drives a need to expand the scope of analysis in operations strategy research to a larger share of the supply chain (Gupta et al., 2006; Hayes, 2002). Researchers must study not only focused factories, that is, focused internal manufacturing operations, but also focused sourcing decisions.

\subsection{Make-buy decisions as a key strategic decision area in operations strategy}

The present research idea, to extend the debate over trade-offs in operations strategy into the theoretical domain of make-buy decisions, fits well with the four key decision areas in operations strategy today. In the work of Slack and Lewis (2008), for example, these decision areas are: (1) capacity, (2) supply networks, (3) process technology, and (4) development and organisation. Make-buy decisions are a fundamental part of the supply networks decision area, but, as mentioned earlier, previous studies have so far overlooked the trade-offs in outsourcing. Rather, most of the outsourcing literature is concerned with the advantages or motives for outsourcing, that is, to reduce costs, increase product quality, increase speed, increase flexibility and take advantage of suppliers' greater innovation capability. The risks involved are clarified in these works but not addressed and articulated in terms of trade-offs (Beaumont and Sohal, 2004; Harland, Knight, Lamming and Walker, 2005; Quélin and Duhamel, 2003). In this study outsourcing manufacturing is defined as a factory arranging to have parts that formerly were manufactured internally provided by an external supplier (Cánez, Platts and Probert, 2000). The decision whether and what to outsource is viewed as a distinct strategic 
choice in devising an operations strategy (Voss, 2005). Furthermore, the term outsourcing manufacturing is used to denote that only manufacturing operations are under investigation in this study, not other kinds of operations such as IT or HR functions. Finally, the term should not be confused with complete outsourcing or contract manufacturing, though this definition includes these types of outsourcing.

The theoretical underpinnings for make-buy decisions can be traced back to both transaction cost economies (TCE) (Williamson, 1975, 1985) and the resource based view (RBV) (Barney, 1991; Peteraf, 1993). The former specifies under which economic conditions an organisation should manage an exchange internally within its boundaries and which are suitable for managing an exchange externally, i.e., outsourcing. The latter views the firm as a bundle of resources that, if employed in distinct capabilities, can create competitive advantage. Such distinct capabilities are viewed as core business (Prahalad and Hamel, 1990) and should consequently be internalized, whereas non-core business is outsourced.

TCE and RBV help to identify a number of critical factors that inform the make-buy decision. Starting with transaction costs, these are defined as the costs of planning, adapting, coordinating and safeguarding exchange (Cousins, Lamming, Lawson and Squire, 2008). The level of transaction cost is determined by two behavioral factors and two transaction factors (Williamson, 1975, 1985).

The behavioral factors are opportunism and bounded rationality. Opportunism refers to seeking self-interest with guile. Not all suppliers will behave opportunistically, but it is impossible for the buying firm to distinguish those who will cooperate and those who will behave opportunistically. Such difficulties and associated costs increase as transactions are characterized by asset specificity. Where there is high potential for opportunism, TCE predicts a greater likelihood the activity will be performed internally (McIvor, 2009). Bounded rationality refers to 
the cognitive limitations of the human mind, which increase the difficulties of fully understanding the complexities of all possible decisions. In uncertain environments, TCE predicts due to bounded rationality that the activity will be performed internally (McIvor, 2009).

The transaction factors are asset specificity and uncertainty. Asset specificity refers to how specialised a particular asset is to a relationship. Highly specialised assets are risky, since the full production value of the asset cannot be transferred if the relationship is terminated ahead of time. A relationship with high asset specificity increases the possibility of opportunism and therefore favors hierarchy, as the specific assets are costly to re-deploy in alternative uses (McIvor, 2009). Transaction-related uncertainty mainly refers to not being able to predict future states of technology, demand or supply (Cousins et al., 2008; Holcomb and Hitt, 2007). TCE predicts that high degrees of uncertainty favor hierarchy. At increasingly higher levels of uncertainty information deficits emerge that lead to a need for renegotiating the terms of the relationship. Asymmetries make it difficult to foresee potential contingencies that may occur in the future, making it costly to write, monitor and enforce complete contracts (Holcomb and Hitt, 2007).

Thus, TCE suggests that due to opportunism and bounded rationality, situations characterized by high degrees of asset specificity and uncertainty tend to favor hierarchy, i.e., making the parts in house. In contrast, low degrees of asset specificity and uncertainty favor market, that is, buying from suppliers.

However, in dealing with make-buy decisions, TCE is not a complete theory. According to McIvor (2009) and Holcomb and Hitt (2007) make-buy decisions also have to be informed by RBV. There are two main reasons for this. First of all, TCE is a theory of cost minimisation, not of value creation. Since many firms compete on sources of competitive advantage other than low costs, such as differentiation, there are reasons for outsourcing despite increased transaction 
costs. An example is when the buying firm cannot develop the capability internally and the supplier has capabilities that create competitive advantage for the buying firm. Secondly, TCE assumes that capabilities pre-exist or can be developed equally among all firms in an industry, which means that they should all act identically regarding vertical integration. However, this is not a true reflection of reality. Capabilities are not spread evenly among firms and are dependent on the unique trajectories of individual firms (Cousins et al., 2008). One example is the telecom industry, where major actors have chosen completely different outsourcing strategies. Berggren and Bengtsson (2004) revealed this when they studied the contrasting outsourcing strategies of Ericsson and Nokia, finding that Ericsson had embarked on an extensive outsourcing strategy driven by modular product design and component standardisation, while Nokia's strategy was based on integral product design and low levels of outsourcing.

Thus, if we shift focus from exchange conditions to value chain structures that create competitive advantage, there are reasons for outsourcing despite increased transaction costs. Collaboration through outsourcing allows a buying firm to access complementary capabilities in a situation where there are resource constraints (Holcomb and Hitt, 2007). By combining capabilities in unique ways across organisational boundaries, buying firms can obtain competitive advantage over their competitors (Dyer and Singh, 1998). However, this necessitates strategic relatedness, the degree to which firms are strategically similar (Holcomb and Hitt, 2007). Similarity may mean relying on similar technologies or utilising similar production or supply chain systems. Strategic relatedness implies that the focal firm and its supplier share common goals and are able to transfer knowledge between them effectively (ibid.). Since goals are often manifested as competitive priorities in a manufacturing context (McIvor, 2009), the competitive priorities of the buying firm must match the distinct capabilities that the supplier offers. This implies that outsourcing motives have to mirror both the competitive priorities of the buying firm 
and the capabilities of the supplier. Consequently, since there are five competitive priorities (cost, quality, speed, flexibility and innovation) there are mainly five strategic outsourcing motives (Kroes and Ghosh, 2010).

First of all, there is the cost motive. Reduced costs can be achieved if the supplier provides goods or services to many customers, often referred to as external economies of scale. Asset specificity and uncertainty should in this case be low. Fixed costs can be lowered by having a common production platform that is used by several customers and therefore results in increased utilisation of factory space and machinery. Lower variable costs can be achieved through having operations in low-wage countries, purchasing scale, and/or by engineering competence that helps in altering product design to incorporate cheaper and better components. In addition, standardizing manufacturing processes leads to possibilities for continuous improvements.

Secondly, there is the quality motive. Outsourcing partners generally have more experience in manufacturing the specific parts and in consequence can provide higher quality. In addition, manufacturing the outsourced parts is often a core capability at the supplier level. Therefore, the supplier should be able to achieve higher operating performance levels in areas such as product quality. A high-quality capability is generally the end result of a time-consuming development process where certain abilities are developed by changed organisational behaviour patterns (Bessant, Caffyn and Gallagher, 2001; Dabhilkar and Bengtsson, 2007; Powell, 1995).

Thirdly, there is the speed motive. Specialised suppliers can offer faster throughput time and less queuing through investments in dedicated process technology, thereby trying to maintain capacity flexibility to buffer against demand and supply uncertainty. Their inventory strategy is generally to buffer inventory to deal with demand and supply uncertainty and often to attempt to 
reduce lead times aggressively even if the associated costs are significant (Chopra and Meindl, 2010; Fisher, 1997).

Fourthly, there is the flexibility motive, where the focal firm tries to improve its responsiveness to variability in demand by outsourcing to specialist suppliers. The underlying capability at the supplier stage is often similar to speed, that is, investments in process technology. Rapid changes in technology, reduced time to market and increasingly sophisticated customers make it very difficult for original equipment manufacturers to excel at all activities that create competitive advantage. Outsourcing can provide the buying firm with flexibility, particularly when sourcing rapidly developing new technologies. Specialist suppliers can provide greater responsiveness than large, vertically integrated organisations since demand is aggregated for several customers (McIvor, 2005).

Fifth and finally, there is the innovation motive, where the focal firm tries to take advantage of the supplier's higher innovation capability, to improve the overall performance of its end product. In many supply markets there exist significant opportunities to leverage the capabilities of suppliers into the product of the customer organisation (McIvor, 2005). Rather than trying to replicate the capabilities of a supplier network it can be much more effective to use outsourcing to fully exploit the suppliers' investments, innovations and specialised capabilities (ibid.).

\subsection{Trade-offs in make-buy decisions}

As shown above, TCE and RBV help to identify a number of critical factors that underpin the five main outsourcing motives. However, the present study argues that these motives often conflict, which implies that firms cannot have it all when outsourcing manufacturing. Thus, while previous studies used TCE and RBV to derive outsourcing motives, they have so far overlooked 
that these theoretical underpinnings also have to be used to assess trade-off implications involved in make-buy decisions. The present study attempts to fill this gap in the operations strategy literature by utilising TCE and RBV to extend the debate over trade-offs to make-buy decisions.

So why do firms have to sacrifice performance improvements in some capabilities in order to excel in others when outsourcing manufacturing? This study suggests that there are three reasons. The first two reasons can be linked to the TCE factors asset specificity and uncertainty, and the third reason can be linked to the RBV factors complementary capabilities and strategic relatedness.

The first issue, asset specificity, or more particularly transaction-specific investments, is necessary to leverage the supplier capability sought. When outsourcing strategies are influenced by the buying firm's competitive priorities in terms of cost, quality, speed, flexibility and innovation, this strategy should be evident in the criteria used to select and retain suppliers. Firms often spend considerable time and money choosing an outsourcing partner. The supplier selection effort often involves site visits to perform in-depth supplier assessments. If a selected supplier lives up to the initial expectations of the buying firm, the two parties usually invest in transaction-specific investments (Krause et al., 2001). Consequently the relationship becomes more intertwined. As the amount of transaction-specific investment increases, the cost of switching, or not retaining, the supplier becomes higher for the buying firm. As a result, buying firms engage in supplier development activities aimed at improving the supplier's capabilities (ibid.). The important point here is that the collaboration type differs depending on the capability type (cf. Cousins, 2005). When price is prioritised, operational collaboration, such as sharing planning and sales information, developing and sharing forecasts, and linking order management systems, will leverage the supplier's ability to deliver at low cost. On the other hand, when differentiation is prioritised, strategic collaboration will leverage the supplier's ability to deliver 
quickly, change the mix or volume of orders, and design new products or make changes in existing products. This collaboration can involve improved integration between the buyer and supplier, technology sharing, joint product development, and shared production engineering (ibid.). Thus, the first reason why trade-offs exist in make-buy decisions is that the transactionspecific investments that will leverage the supplier's capability is unique for each priority.

The second reason is linked to the other significant TCE-related factor, uncertainty, defined as not being able to predict future states of technology, demand or supply. Trade-offs remain in make-buy decisions because when buying firms compete on speed, flexibility and/or innovation, the implied demand uncertainty will increase. Implied demand uncertainty is defined as demand uncertainty imposed on the supply chain because of the customer needs it seeks to satisfy (Chopra and Meindl, 2010). In order to thrive, firms need to establish strategic fit, or congruence between the implied demand uncertainty and supply chain capabilities. Overall, there are two types of contrasting supply chain capabilities, namely responsiveness and efficiency (Fisher, 1997).

According to Chopra and Meindl (2010), supply chain responsiveness refers to its ability to meet short lead times, respond to a wide range of quantities and varieties, build innovative products, and handle supply uncertainty. Responsiveness, however, comes at a cost. For example, to respond to a wider range of quantities and varieties, capacity must be increased, which increases costs. This increase in costs leads to the other supply chain capability, namely efficiency. Supply chain efficiency is the inverse of the cost of sourcing, making and distributing a product to the final customer. An increase in cost will lower efficiency. For every strategic choice to increase responsiveness, there are additional costs that lower efficiency (cf. Chopra and Meindl, 2010). For instance, in efficient supply chains, suppliers are mainly selected on the basis of low costs they achieve through high utilisation of process technology and equipment. In 
responsive supply chains, on the other hand, suppliers are mainly selected on speed, flexibility and innovation, achieved by maintaining capacity flexibility to buffer against demand uncertainty, even if the associated costs for buffering are significant (ibid.).

The third reason is linked to the RBV factors complementary capabilities and strategic relatedness. The buying firm must exploit complementary capabilities at the supplier stage when outsourcing. This implies that the manufacturing capability of a firm is increasingly derived from a global network of its own factories and from the global network of factories in its supply chain. The consequence is that the operations strategy unit of analysis must change from the factory to the network of factories and the supply chain (Voss, 2005). Taken together with the strategic relatedness factor, the competitive priorities of the buying firm must match the distinct capabilities that the supplier stage offers in order to establish goal congruence. Thus, in response to the shift in unit of analysis, the third reason why trade-offs remain in make-buy decisions is that the competitive capability of a buying firm will be significantly linked to the capabilities of the outsourced operations.

At a more detailed level, the significant link between capabilities of the OEM firm and its supplier can be understood in light of design-manufacturing integration needs. So far, the discussion has only focused on manufacturing, ignoring design activities. However, design and manufacturing decisions are interdependent and should not be analysed in isolation (Ulrich and Ellison, 2005), particularly when sourcing manufacturing of a product-specific part, or family of parts, that is designed internally within the firm. The point here is that even though the manufacturing of a part is externalized it still has to be integrated because the buying firm has to arrange for the completion of a set of interrelated design and production activities in order to deliver its final product to the market (ibid.). 


\subsection{Hypotheses}

Following these three reasons it is hypothesised that trade-offs remain in make-buy decisions.

- Hypothesis A - Strategic outsourcing initiatives lead to distinct capability improvements.

- Hypothesis B - The resulting outsourcing capabilities do not emerge cumulatively.

\section{Research methodology}

\subsection{Sample and data collection approach}

A postal survey was distributed to a disproportionately stratified, random sample of 563 manufacturing plants in the Swedish engineering industry (see Table 1).

\section{[Please insert Table 1 here]}

This sampling technique is suggested when the population consists of subgroups of different sizes (Forza, 2002). After two reminders, 267 of the targeted plants returned the instrument, yielding an overall response rate of $47 \%$. However, the data analysis presented in this article is only based on the 136 manufacturing plants that responded as having outsourced manufacturing operations during the previous three-year period. Outsourcing manufacturing was defined as having an external supplier provide parts or "a family of parts" that formerly were manufactured internally (Cánez et al., 2000).

Statistics Sweden's Business Register 2003 of manufacturing plants with more than 50 employees within ISIC codes $28-35$ was used as the sample frame. Data were collected during early spring 2004; whenever the phrase the studied three-year period is used in the article the calendar years 2001, 2002, and 2003 are meant. The unit of analysis was manufacturing plants of engineering industry companies. In order to detect response bias, researchers contacted by 
telephone a random sample of 98 plants that after two reminders declined to fill in the form and return it. Thirty-four factories agreed to answer five key questions from the original instrument in the following three topic areas: the strategic role of the manufacturing function, the degree of outsourcing manufacturing and factory performance. This enabled a comparison between those that participated in the survey and those that did not. No significant response bias was detected. Those that declined to participate in the telephone interview as well gave the following reasons for not participating in the study: Three units were not proper manufacturing firms and 23 plants were not interested due to lack of time. At the remaining 38 plants it was not possible to contact the production manager during the time of this study. More details on data collection and sample can be found in Dabhilkar (2006).

This database has been used in at least five related studies (Bengtsson, von Haartman and Dabhilkar, 2009; Bengtsson, Dabhilkar and von Haartman, 2011; Dabhilkar and Bengtsson, 2008; Dabhilkar and Bengtsson, 2011; Dabhilkar, Bengtsson, von Haartman and Åhlström, 2009). Some of the data collection procedures are therefore paraphrased. The research approach in this study, however, is entirely novel. Outsourcing congruence and its effects on distinct outsourcing capability development was not examined in these earlier studies. Neither have relationships between resulting outsourcing capabilities, which is an additional purpose of this study.

\subsection{Variables}

The statistical analysis is based on three main constructs and four control variables. The main constructs are (1) competitive priorities, (2) outsourcing motives and (3) resulting outsourcing capabilities, interchangeably referred to in this text as outsourcing performance.

Competitive priorities denote a strategic emphasis on developing certain performance objectives. Since operations strategy is always concerned with addressing customer needs, the 
focus here is on the five generic performance objectives of cost, quality, speed, flexibility and innovation. The point is that each of these performance objectives has both external and internal effects. Externally, their relative importance will differ according to the nature of market requirements that the firm's products are intended to serve. Internally, these help in deploying operations resources to address the needs of a very specific part of the market. One way to determine the relative importance of each performance objective is to use the concept of orderwinners (cf, Slack and Lewis, 2008). Table 2 shows how the competitive priorities construct was operationalised.

\section{[Please insert Table 2 here]}

The construct of outsourcing motives was measured according to the competitive priorities. The reason is that the external environment, on which the firm has little or no influence, usually activates triggers that lead to motives for outsourcing. For instance, increased price competition in the marketplace can be viewed as a trigger that usually forces companies to reduce costs (motive for outsourcing). Cánez et al. (2000) list a wide range of motives that can be grouped into five distinct subsets: reduce costs, increase quality, increase focus, increase responsiveness, increase innovation capability. This grouping is consistent with findings from several empirical studies across various geographical and industrial settings (Beaumont and Sohal, 2004; Kakabadse and Kakabadse, 2002; Quélin and Duhamel, 2003). Table 3 shows how this study measured outsourcing motives.

\section{[Please insert Table 3 here]}

Resulting outsourcing capabilities were measured as performance effects of the outsourcing initiative. Performance indicators were selected to consistently reflect the generic competitive priorities and outsourcing motives (Table 4).

\section{[Please insert Table 4 here]}


The influence from four contextual variables was controlled for, namely: Plant size, Industry type, Order fulfillment practice and Outsourcing intensity. Plant size was measured according to the stratification of the sample (see Table 1), using dummy variables following the example in Field (2005, p. 208). Dummy coding is a way of representing groups of observations using only zeros and ones. To do this, several variables had to be created, one fewer than the number of groups that was recoded. In this case, the sample was stratified into five size groups, hence four dummy variables were created. For Industry type, dummy variables were used as well. In this case, the sample was stratified into eight industry types (see Table 1), so seven dummy variables were created. For order fulfillment practice, respondents were asked to answer "Which of the following alternatives best describe operations at your factory?" on a scale of 1 to 5 , where $1=$ Make to stock, 2 = Assemble to order, $3=$ Produce to order, $4=$ Configure to order, $5=$

Design to order. Finally, outsourcing intensity was measured according to the change in degree of cost for purchased materials as a share of the total manufacturing cost for the main product line during the studied three-year period.

\section{Findings}

In order to test the two underlying hypotheses, data were subjected to regression analysis. Two separate regression analyses were performed. Regression analysis A to test Hypothesis A and Regression analysis B to test Hypothesis B.

\subsection{Regression analysis A}

Hypothesis A posits that strategic outsourcing initiatives lead to distinct capability improvements. This means that firms who win orders on price and therefore outsource from cost motives are predicted to obtain improvements in cost performance, but not in other performance areas, ceteris 
paribus. Likewise, firms that win orders based on customization and therefore outsource from flexibility motives are predicted to obtain improvements in flexibility, but not in other performance areas. Thus, firms can become more cost efficient as a result of outsourcing but not generally more responsive, or vice versa, they may increase their responsiveness but not become more cost efficient at the same time. An important nuance is that while other performance areas will not improve, they do not have to worsen. Trade-offs and related sacrifices in performance just mean a firm cannot "have it all" when outsourcing manufacturing.

Results of Regression analysis A are presented in Table 5. Standardized beta coefficients are shown. Resulting outsourcing capabilities in terms of outsourcing performance are used as dependent variables. Five different outsourcing congruence variables were computed for use as independent variables. These mirror the five competitive priorities and their associated outsourcing motives. To measure congruence, each competitive priority was multiplied with its corresponding outsourcing motive, following the example in Kroes and Ghosh (2010). Finally, four control variables are entered last to check if main effects hold, controlling for size, industry type, order fulfillment practice and outsourcing intensity.

\section{[Please insert Table 5 here]}

Support was found for Hypothesis A. Strategic outsourcing initiatives lead to distinct capability improvements as hypothesised. Table 5 shows that models 1-5 all explain a significant share of variance in each of the dependent variables. More importantly, this variance is only explained by one independent variable at a time, and furthermore by the corresponding outsourcing initiative. Thus, the cost outsourcing congruence variable is the sole predictor of improved performance in outsourcing cost. The quality outsourcing congruence variable is the sole predictor of outsourcing quality performance, and so forth. 
However, there is one drawback with using outsourcing congruence variables as in Regression analysis A. There are many more possible combinations of competitive priorities and outsourcing motives that are not accounted for in the analysis, some of which might lead to cumulative development of outsourcing capabilities. Due to multicolinearity issues and the limited sample size, it is not possible to include all possible combinations in the regression analysis. Simply put, there will be too many variables in the analysis. Instead, Regression analysis B is performed to exclude the possibility that resulting outsourcing capabilities emerge cumulatively.

\subsection{Regression analysis $B$}

Results of Regression analysis B are shown in Table 6. In this regression analysis only resulting outsourcing capability variables are used as either dependent or independent variables. For example, in Model 1 cost performance is used as dependent variable and the remaining outsourcing capability variables measuring quality, speed, flexibility and innovation are used as independent variables. Naturally, since the cost variable is already used as dependent variable in Model 1, it cannot be used at the same time as an independent variable in the same model. Therefore, the abbreviation NA, not applicable, is used in Table 6 to denote this. Finally, control variables are added last to control for the effects of firm size, industry type, order fulfillment practice and outsourcing intensity.

\section{[Please insert Table 6 here]}

Overall, support is found for Hypothesis B, that resulting outsourcing capabilities do not emerge cumulatively. However, the results are not as clean as in the former regression analysis, mainly because improved quality is significantly related to cost reductions (Model 1), improved speed (Model 3) and innovation (Model 5). This is also shown all together in Model 2, where 
quality is used as dependent variable and predicted well by cost reductions, improved speed and innovation. Without knowing the exact reason for this, we can speculate that outsourcing partners generally have more fabrication experience in manufacturing specific parts and thus can provide higher quality (Leiblein and Miller, 2003). Quality and flexibility, however, are not related, as can be seen in Model 4. Perhaps flexibility requirements entail high degrees of uncertainty, which contradicts the development of standards for quality improvement.

The most important finding though, in light of the tested research hypothesis, is that tradeoffs remain in make-buy decisions. In Model 1 in Table 6, for example, cost reductions are not predicted well by improvements in speed, flexibility or innovation. Likewise, in models 3-5 in Table 6, where speed, flexibility and innovation, respectively, are predicted, cost reduction can not be shown to predict any of these dependent variables. Thus, cost efficiency (in terms of reduced costs of outsourced parts) and responsiveness (in terms of increased speed, flexibility and innovation) are independent outsourcing capabilities.

\section{Discussion and conclusion}

While the debate over trade-offs in operations strategy has so far been confined within factory walls, the present study extends this research into the supply chain by addressing trade-offs in make-buy decisions. Outsourcing scholars often routinely assume that trade-offs between cost and flexibility can be overcome (see e.g. Brusoni et al., 2001, p. 599: "firms aim to exploit flexibility and to cut costs by outsourcing production". As this is true, on the one hand, in view of scale economies and the aggregation of demand at the supplier stage, the present study has clarified why trade-offs remain in make-buy decisions for the buying firm.

The analysis is based on a representative sample of the manufacturing sector in Sweden within ISIC 28-35. Regression analysis shows that strategic outsourcing initiatives lead to distinct 
capabilities that mirror a firm's competitive priorities and that furthermore do not emerge cumulatively. That is, while outsourcing improves cost efficiency and responsiveness, respectively, there is no evidence that these two resulting outsourcing capabilities improve simultaneously when outsourcing manufacturing. These statistical results hold even after controlling for firm size, industry type, order fulfillment practice and outsourcing intensity.

This study strongly resembles but is also strikingly different from other recent related research in the area. Kroes and Ghosh (2010) show that outsourcing congruence with competitive priorities leads to improved supply chain performance. The resemblance between this and their study is our common focus on outsourcing congruence. Outsourcing congruence is measured in the same way. However, the difference is in the dependent variable. Kroes and Ghosh use a composite construct of supply chain performance, which overlooks individual differences between resulting capabilities. Also, flexibility and innovation are omitted in their study. Thus, the value of this study is to show that resulting capabilities of an outsourcing initiative are distinct, and with regards to the debate over trade-offs in operations strategy, this study has provided clear empirical evidence in favor of the trade-off model.

The study utilises TCE and RBV to explain why trade-offs remain in make-buy decisions. Three possible reasons are offered. First, transaction-specific investments are needed to leverage the capabilities of the supplier (Krause et al., 2001). Investments are specific for every competitive priority and therefore different depending on the capability sought (Cousins et al., 2005). Secondly, competitive priorities such as speed, flexibility and innovation cause implied demand uncertainty to increase (Chopra and Meindl, 2010; Fisher, 1997). This increase in uncertainty creates a need for supply chain responsiveness, which increases cost (ibid.). Third, outsourcing entails a shift in unit of analysis (Voss, 2005). The unit of analysis also has to involve the supplier's operations, since the buying firm becomes dependent on the 
complementary capability of its supplier; due to needs of strategic relatedness, competitive priorities have to be aligned across firms (Holcomb and Hitt, 2007; McIvor, 2009).

The conclusion that follows is that make-buy decision frameworks that fail to consider trade-offs inherent in competitive priorities are incomplete. Outsourcing scholars need to sharpen make-buy decision frameworks in future research. That is, we must not only point out motives for outsourcing, but also clarify that these motives are often in conflict, which implies that decision makers need to prioritise when outsourcing manufacturing. As the outsourcing trend increase there is a clear need for focused sourcing decisions. This research informs the use of for example analytic hierarchy process to the selection of suppliers (Cousins et al., 2008) by clarifying realistic expectations when outsourcing. Conflicts occur between outsourcing motives because even when an activity is externalized, i.e., outsourced, it still has to be integrated across firms and fulfil a need in the buying firm. This reality is a blind spot in the traditional make-buy literature, which is mainly concerned with aiding decisions about which activities to externalize and which suppliers to select. Competitive priorities bring it to the fore because that places greater emphasis on (re-)integration needs.

Outsourcing, although often unavoidable, presents both difficulties and paradoxes that have yet to be fully understood or addressed by most analysts and strategists. On the one hand, outsourcing is often both desirable and necessary. On the other, everything outsourced needs to be re-integrated, and the cost of this can be significant and depends crucially on specialised investments in certain relationship types. Therefore, when designing an outsourcing strategy, the benefits of outsourcing (including direct cost reductions, for example in manufacturing, and access to specialised external skills and technologies) need to be set against not only the explicit 
and direct costs of outsourcing, but also less obvious costs of building the necessary skills and capabilities, structures and processes needed for this extended re-integration.

The implication for managers is that firms cannot have it all but instead need to appreciate and balance these trade-offs and establish congruence between firm competitive strategy and outsourcing motives. For example, firms who win orders on price and therefore outsource from cost motives may obtain improvements in cost performance, but not in other performance areas. Likewise, firms that win orders based on customization and therefore outsource from flexibility motives may obtain improvements in flexibility, but not in other performance areas. Thus, firms can become more cost efficient as a result of outsourcing but do not generally become more responsive at the same time.

\section{Epilogue}

During the spring of 2008, I was asked by a major Swedish business law firm to testify as an outside expert in a dispute chaired by the Arbitration Institute of the Stockholm Chambers of Commerce. The dispute was between a contract manufacturer (CM) and an original equipment manufacturer (OEM), both public Swedish firms. The CM is among the leading Nordic contract manufacturers and the OEM is a world-leading developer of mobile satellite communications equipment. The assignment as outside expert gave rise to this analysis. If firms end up in court, these are difficult issues that need attention. Furthermore, the existing literature at that time did not explicitly address these issues, another reason to write this paper.

The dispute concerned the potential for cost reductions. The contract stipulated cost reductions over a three-year period. However, these cost reductions never materialized; my assignment was to explain why. In brief, my argument was that there was no potential for cost reductions. The reason was that the outsourced product was at the introduction stage of the 
product life cycle. The OEM firm won orders based on product novelty, customization and fast response. It was very difficult to forecast demand and there was a constant stream of engineering change orders even as the product was being produced. These circumstances are quite normal in the early stages of the product life cycle but dilute the impact of reduced costs associated with cost drivers such as scale economics.

The arbitration board ruled in favour of the CM.

\section{REFERENCES}

Barney, J., 1991. Firm resources and sustained competitive advantage. Journal of Management $17(1), 99-120$.

Beaumont, N., Sohal, A., 2004. Outsourcing in Australia. International Journal of Operations \& Production Management 24 (7), 688-700.

Bengtsson, L., Dabhilkar, M., von Haartman, R., 2011. Knowledge integration challenges when outsourcing manufacturing. In: Berggren, C. Bergek, A., Bengtsson, L., Söderlund, J., Hobday, M. (Eds.). Knowledge Integration and Innovation: Critical Challenges Facing International Technology-Based Firms. Oxford University Press, Oxford.

Bengtsson, L., von Haartman, R., Dabhilkar, M., 2009. Low-cost versus innovation: Contrasting outsourcing and integration strategies in manufacturing. Creativity and Innovation Management 18 (1), 35-47.

Benningson, L., 1996. Changing manufacturing strategy. Production and Operations Management 5 (1), 91-102.

Berggren, C., Bengtsson, L., 2004. Rethinking outsourcing in manufacturing: A tale of two telecom firms. European Management Journal 22 (2), 211-223.

Bessant, J., Caffyn, S., Gallagher, M., 2001. An evolutionary model of continuous improvement behaviour. Technovation 21 (2), 67-77. 
Boyer, K. K., Lewis, M. W., 2002. Competitive priorities: Investigating the need for trade-offs in operations strategy. Production and Operations Management 11 (1), 9-20.

Brusoni, S., Prencipe, A., Pavitt, K., 2001. Knowledge specialization, organizational coupling, and the boundaries of the firm: Why do firms know more than they make? Administrative Science Quarterly 46 (4), 597-621.

Cánez, L. E., Platts, K. W., Probert, D. R., 2000. Developing a framework for make-buy decisions. International Journal of Operations \& Production Management 20 (11), 13131330.

Chopra, S., Meindl, P., 2010. Supply chain management: Strategy, planning and operation. Pearson, Upper Saddle River, NJ.

Clark, K., 1996. Competing through manufacturing and the new manufacturing paradigm: Is manufacturing strategy passé? Production and Operations Management 5 (1), 42-58.

Cousins, P. D., 2005. The alignment of appropriate firm and supply strategies for competitive advantage. International Journal of Operations \& Production Management 25 (5-6), 403-428.

Cousins, P. D., Lamming, R., Lawson, B., Squire, B., 2008. Strategic Supply Management: Principles, Theories and Practice. Pearson Education, Harlow, UK.

Dabhilkar, M., 2006. Acting creatively for enhanced performance: Challenges for Swedish manufacturers in an age of outsourcing. Doctoral dissertation, Royal Institute of Technology, Stockholm.

Dabhilkar, M., 2011. Trade-offs in make-buy decisions: Exploring operating realities of knowledge integration and innovation. In: Berggren, C., Bergek, A., Bengtsson, L., Söderlund, J., and Hobday, M. (Eds.). Knowledge Integration and Innovation: Critical Challenges Facing International Technology-Based Firms. Oxford University Press, Oxford. 
Dabhilkar, M., Bengtsson, L., 2007. Continuous improvement capability in the Swedish engineering industry. International Journal of Technology Management 37 (3-4), 272-289.

Dabhilkar, M., Bengtsson, L., 2008. Invest or divest? On the relative improvement potential in outsourcing manufacturing. Production Planning \& Control 19 (3), 212-228.

Dabhilkar, M., Bengtsson, L., von Haartman, R., Åhlström, P., 2009. Supplier selection or collaboration? Determining factors of performance improvement when outsourcing manufacturing. Journal of Purchasing and Supply Management 15 (3), 143-153.

Dyer, J. H., Singh, H., 1998. The relational view: Cooperative strategy and sources of interorganizational competitive advantage. Academy of Management Review 23 (4), 660679.

Ferdows, K., De Meyer, A., 1990. Lasting improvements in manufacturing performance: In search of a new theory. Journal of Operations Management 9 (2), 168-184.

Field, A., 2005. Discovering Statistics Using SPSS. SAGE, London.

Fisher, M. L., 1997. What is the right supply chain for your product? Harvard Business Review 75 (2), 105-.

Forza, C., 2002. Survey research in operations management: A process-based perspective. International Journal of Operations \& Production Management 22 (2), 152-194.

Gupta, S., Verma, R., Victorino, L., 2006. Empirical research published in Production and Operations Management (1992-2005): Trends and future research directions. Production and Operations Management 15 (3), 432-448.

Harland, C., Knight, L., Lamming, R., Walker, H., 2005. Outsourcing: Assessing the risks and benefits for organizations, sectors and nations. International Journal of Operations \& Production Management 25 (9), 831-850. 
Hayes, R. H., 2002. Challenges posed to operations management by the "new economy". Production and Operations Management 11 (1), 21-32.

Hayes, R. H., Pisano, G., 1996. Manufacturing strategy at the intersection of two paradigm shifts. Production and Operations Management 5 (1), 25-41.

Holcomb, T. R., Hitt, M. A., 2007. Toward a model of strategic outsourcing. Journal of Operations Management 25 (2), 464-481.

Kakabadse, A., Kakabadse, N., 2002. Trends in outsourcing: Contrasting USA and Europe. European Management Journal 20 (2), 189-198.

Krause, D. R., Pagell, M., Curkovic, S., 2001. Toward a measure of competitive priorities for purchasing. Journal of Operations Management 19 (4), 497-512.

Kroes, J. R., Ghosh, S., 2010. Outsourcing congruence with competitive priorities: Impact on supply chain and firm performance. Journal of Operations Management 28 (2), 124-143.

Lapre, M. A., Scudder, G. D., 2004. Performance improvement paths in the US airline industry: Linking trade-offs to asset frontiers. Production and Operations Management 13 (2), 123134.

Leiblein, M. J., Miller, D. J., 2003. An empirical examination of transaction- and firm-level influences on the vertical boundaries of the firm. Strategic Management Journal 24 (9), 839859.

McIvor, R., (2005). The outsourcing process: Strategies for evaluation and management.Cambridge University Press, Cambridge.

McIvor, R., 2009. How the transaction cost and resource-based theories of the firm inform outsourcing evaluation. Journal of Operations Management 27 (1), 45-63.

Nakane, J., 1986. Manufacturing Futures Survey in Japan: A Comparative Survey 19831986. Waseda University, Tokyo. 
Peteraf, M. A., 1993. The cornerstones of competitive advantage: A resource-based view. Strategic Management Journal 14 (3), 179-191.

Powell, T. C., 1995. Total quality management as competitive advantage - A review and empirical study. Strategic Management Journal 16 (1), 15-37.

Prahalad, C. K., G. Hamel. 1990. The core competence of the corporation. Harvard Business Review, 68 (3), 79-91.

Quélin, B., Duhamel, F., 2003. Bringing together strategic outsourcing and corporate strategy: Outsourcing motives and risks. European Management Journal 21 (5), 647-661.

Rosenzweig, E. D., Roth, A. V., 2004. Towards a theory of competitive progression: Evidence from high-tech manufacturing. Production and Operations Management 13 (4), 354-368.

Schmenner, R. W., Swink, M. L., 1998. On theory in operations management. Journal of Operations Management 17 (1), 97-113.

Schonberger, R., 1986. World Class Manufacturing: The Lessons of Simplicity Applied.Free Press, New York.

Skinner, W. 1969. Manufacturing: Missing link in corporate strategy. Harvard Business Review, 47 (3), 136-145.

Skinner, W. 1974. The focused factory. Harvard Business Review, 52 (3), 113-120.

Skinner, W., 1996. Manufacturing strategy on the 'S' curve. Production and Operations Management 5 (1), 3-14.

Slack, N., Lewis, M., 2008. Operations Strategy. Financial Times Prentice Hall, Harlow, UK.

Ulrich, K. T., Ellison, D. J., 2005. Beyond make-buy: Internalization and integration of design and production. Production and Operations Management 14 (3), 315-330.

Vastag, G., 2000. The theory of performance frontiers. Journal of Operations Management 18 (3), 353-360. 
Voss, C., 2005. Paradigms of manufacturing strategy re-visited. International Journal of Operations \& Production Management 25 (12), 1223-1227.

Williamson, O. E., 1975. Markets and hierarchies. Free Press, New York.

Williamson, O. E., 1985. The economic institutions of capitalism: Firms, markets and relational contracting.Free Press, New York. 


\section{[TABLES]}

Table 1. Sample characteristics and response rate

\begin{tabular}{|l|c|c|c|c|c|c|}
\hline & \multicolumn{7}{|c|}{ Stratum (number of employees) } \\
\hline & $50-99$ & $100-199$ & $200-499$ & $500-999$ & $1000+$ & $\sum$ \\
\hline & & & & & & \\
\hline Population (ISIC 28-35) & 466 & 241 & 155 & 48 & 28 & 938 \\
\hline Target sample & 188 & 144 & 155 & 48 & 28 & 563 \\
\hline Answered the survey & 80 & 77 & 69 & 24 & 17 & 267 \\
\hline Response rate & $43 \%$ & $53 \%$ & $45 \%$ & $50 \%$ & $61 \%$ & $47 \%$ \\
\hline $\begin{array}{l}\text { Focus in this study: } \\
\text { Has outsourced manufacturing operations } \\
\text { during the last 3 years } \\
\text { (No = 0 / Yes = 1) }\end{array}$ & 34 & 44 & 33 & 15 & 10 & 136 \\
\hline
\end{tabular}

Note: Key to ISIC codes: $28=$ Fabricated metal products; $29=$ Machinery and equipment; $30=$ Office machinery and computers; $31=$ Electrical machinery and apparatus not elsewhere classified; $32=$ Radio, television, and communication equipment and apparatus; $33=$ Medical, precision and optical instruments, watches, and clocks; $34=$ Manufacture of motor vehicles, trailers and semi-trailers; 35 = Other transport equipment. 
Table 2. Measurement of firm competitive priorities

\begin{tabular}{|l|l|l|l|}
\hline Competitive priority & Survey item & Mean & Std dev \\
\hline & & & \\
\hline Cost & Product price & 3.36 & 1.10 \\
\hline Quality & Product quality & 4.31 & 0.63 \\
\hline Speed & Lead time, order to delivery & 3.58 & 0.92 \\
\hline Flexibility & Customization of products & 3.52 & 1.18 \\
\hline Innovation & Product functionality & 4.27 & 0.89 \\
\hline
\end{tabular}

Note: The question was posed as follows: Why do your customers select you?

Please estimate the importance of the following factors. (Five-point Likert scales were used, where 1 = Less important, 5 = Completely determining) 
Table 3. Measurement of outsourcing motives

\begin{tabular}{|l|l|l|l|}
\hline Outsourcing motive & Survey item & Mean & Std dev \\
\hline & & & \\
\hline Cost & Reduce cost for outsourced parts & 3.63 & 1.49 \\
\hline Quality & Increase product quality & 1.90 & 1.22 \\
\hline Focus & Increase focus & 2.75 & 1.45 \\
\hline Flexibility & Increase ability to manage fluctuations in demand & 3.16 & 1.44 \\
\hline Innovation & Take advantage of supplier's higher innovation capability & 1.88 & 1.10 \\
\hline
\end{tabular}

Note: The survey question was posed as follows: How important were the following motives for your outsourcing of manufacturing during the last three years? (Five-point Likert scales were used, where $1=$ Not a motive, $5=$ Decisive motive) 
Table 4. Measurement of resulting outsourcing capabilities

\begin{tabular}{|l|l|l|l|}
\hline Resulting outsourcing capability & Survey item & Mean & Std dev \\
\hline & & & \\
\hline Cost & Cost for outsourced part(s) & 4.90 & 1.46 \\
\hline Quality & Quality & 4.07 & 1.07 \\
\hline Speed & Manufacturing lead times & 3.93 & 1.23 \\
\hline Flexibility & Ability to manage fluctuations in demand & 4.95 & 1.02 \\
\hline Innovation & New functionality of outsourced part(s) & 4.05 & 0.67 \\
\hline
\end{tabular}

Note: The question was posed as follows: What was the effect of your outsourcing initiative on the following performance indicators? (A seven-point Likert scale was used for each indicator ( $1=$ Much worse, $4=$ No effects, 7 $=$ Much better). 
Table 5. Regression analysis A - Standardized beta coefficients

\begin{tabular}{|c|c|c|c|c|c|}
\hline & Cost & Quality & Speed & Flexibility & Innovation \\
\hline & Model 1 & Model 2 & Model 3 & Model 4 & Model 5 \\
\hline \multicolumn{6}{|l|}{ Independent variables } \\
\hline \multicolumn{6}{|l|}{ Outsourcing congruence } \\
\hline Price_CP x Cost_OM & $0.31 * *$ & -0.11 & $-0.19 *$ & -0.09 & -0.03 \\
\hline Quality_CP x Quality_OM & -0.10 & $0.55 * *$ & 0.06 & -0.10 & 0.18 \\
\hline Lead time_CP x Focus_OM & 0.02 & 0.02 & $0.21 *$ & -0.06 & -0.02 \\
\hline Customization_CP x Responsiveness_OM & -0.01 & -0.07 & 0.15 & $0.40 * *$ & 0.00 \\
\hline Functionality_CP x Innovation_OM & 0.11 & -0.10 & 0.11 & -0.03 & $0.27 *$ \\
\hline \multicolumn{6}{|l|}{ Control variables } \\
\hline \multicolumn{6}{|l|}{ Size } \\
\hline 50-99 vs. $100-199$ dummy & 0.03 & -0.09 & $-0.24^{*}$ & 0.10 & 0.09 \\
\hline 50-99 vs. $200-499$ dummy & 0.01 & 0.09 & $-0.30 * *$ & 0.03 & 0.10 \\
\hline 50-99 vs. 500-999 dummy & 0.06 & 0.04 & -0.03 & -0.07 & 0.00 \\
\hline 50-99 vs. $1000+$ dummy & -0.14 & -0.16 & $-0.24 *$ & -0.10 & 0.10 \\
\hline \multicolumn{6}{|l|}{ Industry type } \\
\hline ISIC 28 vs. 29 dummy & -0.10 & 0.04 & 0.00 & -0.03 & -0.07 \\
\hline ISIC 28 vs. 30 dummy & 0.05 & 0.12 & 0.01 & -0.07 & 0.00 \\
\hline ISIC 28 vs. 31 dummy & -0.06 & 0.04 & 0.03 & -0.04 & 0.00 \\
\hline ISIC 28 vs. 32 dummy & 0.06 & 0.01 & 0.00 & -0.06 & -0.16 \\
\hline ISIC 28 vs. 33 dummy & -0.04 & -0.13 & -0.15 & 0.04 & 0.00 \\
\hline ISIC 28 vs. 34 dummy & -0.19 & -0.06 & -0.08 & -0.07 & -0.06 \\
\hline Order fulfillment practice & -0.06 & -0.04 & 0.02 & 0.07 & -0.06 \\
\hline Outsourcing intensity & -0.09 & 0.06 & 0.04 & 0.08 & 0.08 \\
\hline $\operatorname{Adj} R 2$ & 0.07 & 0.20 & 0.10 & 0.12 & 0.09 \\
\hline$F($ full model $)$ & $2.97 *$ & $7.54 * *$ & $2.37 *$ & $5.00 * *$ & $1.90 *$ \\
\hline$N$ & 135 & 134 & 134 & 134 & 134 \\
\hline
\end{tabular}

Note: Resulting outsourcing capabilities used as dependent variable.

$*=\mathrm{p}<0.05, * *=\mathrm{p}<0.01$ (two-tailed). $\mathrm{CP}=$ Competitive Priority, $\mathrm{OM}=$ Outsourcing Motive 
Table 6. Regression analysis B - Standardized beta coefficients

\begin{tabular}{|c|c|c|c|c|c|}
\hline & Cost & Quality & Speed & Flexibility & Innovation \\
\hline & Model 1 & Model 2 & Model 3 & Model 4 & Model 5 \\
\hline \multicolumn{6}{|l|}{ Independent variables } \\
\hline \multicolumn{6}{|l|}{ Resulting outsourcing capabilities } \\
\hline Cost & NA & $0.17 *$ & 0.02 & 0.06 & 0.05 \\
\hline Quality & $0.22 *$ & NA & $0.38 * *$ & -0.14 & $0.30 * *$ \\
\hline Speed & 0.03 & $0.36 * *$ & NA & $0.22 *$ & 0.09 \\
\hline Flexibility & 0.06 & -0.11 & $0.18 *$ & NA & -0.11 \\
\hline Innovation & 0.06 & $0.26 * *$ & 0.08 & -0.12 & NA \\
\hline \multicolumn{6}{|l|}{ Control variables } \\
\hline \multicolumn{6}{|l|}{ Size } \\
\hline 50-99 vs. $100-199$ dummy & 0.07 & -0.07 & -0.15 & 0.20 & $0.23 *$ \\
\hline 50-99 vs. 200-499dummy & 0.12 & -0.07 & -0.16 & 0.15 & 0.17 \\
\hline 50-99 vs. 500-999 dummy & 0.00 & -0.10 & 0.07 & -0.07 & 0.01 \\
\hline 50-99 vs. $1000+$ dummy & -0.07 & -0.15 & -0.11 & 0.00 & $0.22 *$ \\
\hline \multicolumn{6}{|l|}{ Industry type } \\
\hline ISIC 28 vs. 29 dummy & -0.13 & 0.14 & -0.05 & 0.04 & -0.01 \\
\hline ISIC 28 vs. 30 dummy & 0.02 & 0.13 & -0.02 & -0.04 & -0.10 \\
\hline ISIC 28 vs. 31 dummy & -0.03 & 0.01 & 0.01 & -0.05 & 0.02 \\
\hline ISIC 28 vs. 32 dummy & 0.07 & 0.09 & -0.03 & -0.03 & -0.23 \\
\hline ISIC 28 vs. 33 dummy & -0.02 & -0.04 & -0.13 & 0.03 & 0.06 \\
\hline ISIC 28 vs. 34 dummy & -0.18 & 0.06 & -0.08 & -0.09 & 0.03 \\
\hline ISIC 28 vs. 35 dummy & 0.05 & 0.15 & $-0.19 *$ & 0.09 & 0.00 \\
\hline Order fulfillment practice & -0.05 & -0.06 & 0.04 & 0.10 & -0.09 \\
\hline Outsourcing intensity & -0.05 & -0.03 & 0.05 & 0.10 & 0.11 \\
\hline Adj $R 2$ & 0.06 & 0.25 & 0.20 & 0.03 & 0.12 \\
\hline$F($ full model $)$ & $2.34 *$ & $3.54 * *$ & $2.93 * *$ & 1.23 & $2.10 *$ \\
\hline$N$ & 132 & 134 & 134 & 134 & 133 \\
\hline
\end{tabular}

Note: Resulting outsourcing capabilities used as dependent variable.

$$
*=\mathrm{p}<0.05, * *=\mathrm{p}<0.01 \text { (two-tailed) }
$$


